\title{
Letter from the Editor
}

This issue features three papers related to family businesses, as part of Management and Organization Review's effort to address research on family businesses in China and other transforming economies. The papers were all accepted by Senior Editor Xiaowei Rose Luo at INSEAD and her ERB team, who shepherded these papers to publication in MOR.

I encourage further indigenous research on family business, and as an indication of our interest in it, Management and Organization Review and Cambridge University Press created a collection of papers on family business previously published in MOR. Senior Editor Luo introduces this collection with an essay highlighting the wide range of research opportunities related to family businesses in China and other transition economies. The collection will be available for free download through October 31, 2018.

The literature on family businesses is extensive, with the majority of published papers on developed economies. However, the phenomenon in transforming economies is largely unexplored. A quick and necessarily incomplete review of International Business journals finds over 167 papers on the topic of family businesses (eight of which in the context of China were published in Management and Organization Review). The 2018 IACMR conference program lists only one paper (out of 224) with 'family business' in the title.

Miller, Le-Breton Miller, Lester, and Canella (2007) define family businesses as 'firms in which multiple members of the same family are involved as major owners or managers, either contemporaneously or over time'. This definition serves as good starting point for research on family businesses in China and other transition economies. According to the Family Firm Institute (https://ffi. site-ym.com/page/globaldatapoints/), the economic contribution, impact, and scope of family enterprises across the world is undeniably, and perhaps surprisingly, extremely significant. For example, as of 2017 family firms account for two-thirds of all businesses, create 70\%-90\% of annual global gross domestic product (GDP), and account for $50 \%-80 \%$ of jobs in most countries.

A comparison of Brazil, China, and India with the US and Germany is revealing. Family businesses account for 90\% (Brazil), 86\% (China), 90\% (India), 80\%90\% (the US), and 95\% (Germany) of private sector firms, and 86\%, 66\%, 79\%, 
$63 \%$, and $57 \%$, respectively, of the workforce is employed in a family business. Moreover, $85 \%, 65 \%, 60 \%, 57 \%$, and $55 \%$, respectively, of GDP comes from family businesses.

The literature on family businesses covers a range of topics far wider than I can summarize here. De Massis, Majocchi, and Piscitello (2018) provide a comprehensive review of the literature. However, the inescapable conclusion is that research on family enterprises in transforming economies is an underexplored research area. Moreover, the phenomenon of family businesses that emerge as leaders in their niche or sector is almost entirely under researched. Simon (1996, 2009) highlights the German 'hidden champions', most of which are family-owned small- and medium-size enterprises (SMEs), which are the backbone of German manufacturing and are called 'hidden' because they are not well known. However, Mckiernan and Purg (2013) report that the phenomenon of companies that are champions in their niche or sector can be found in Greece, Turkey, Central and Eastern Europe (Russia, former Soviet Republics, and Eastern Europe), and China (Lei, 2018). Although China, India, and Latin America are three regions where family businesses account for a high percentage of employment and contribution to GDP, research is lacking on the history, emergence, and evolution of familyowned businesses in general, especially on niche and sector leaders. Topics such as socioemotional wealth (Gomez-Mejía, Haynes, Núñez-Nickel, Jacobson, \& Moyano-Fuentes, 2007) as a reason that some founders and family successors strive to become niche or sector leaders are clearly under researched. Similarly, research is lacking on the role of institutional voids, venture capitalist investment in potential leaders, or innovation leaders (Florida \& Kenney, 1998), handing over firms from founders to the next of kin, leadership, management philosophies reflected in beliefs such as zhongyong and Confucianism, internalization, corporate social responsibility, the impact of family members in middle management, and the relationship with urban and provincial policy makers and regulators.

Research on family businesses in China and other transforming economies is greatly needed, and it aligns with the MOR initiative to encourage research on phenomena that can break new ground in engaged indigenous scholarship on topics that are relevant and potentially impactful for transforming economies striving to escape the middle-income trap as exemplified in the Chinese initiative 'Made in China 2025'.

In response to a resurgence of published papers in MOR on social networks, I am pleased to welcome back Professor Yanjie Bian (University of Minnesota, USA, and Xi'an Jiatong University, China) as Senior Editor on social networks and informal networks. He joins Sven Horak (St. John's University), Fida Afiouni (American University of Beirut), Alena Ledeneva (University College London), and MOR Senior Editor Maral Muratbekova-Touron (ESCP Europe, Paris) as guest editors of a Special Issue on 'Social Networks: The Dark and Bright Sides of Informal Networks'. The call for papers appears in this issue. Although research on organizing and managing via interpersonal relations has a rich history in 
the management and organization-oriented literature, the informal dimension of managing and organizing by drawing on informal networks in an international context has received less attention and is the purpose of this special issue.

Lastly, I wish to draw your attention to two papers that appear in the Dialogue, Debate, and Discussion section of MOR, by Professor and Editor-in-Chief of Administrative Science Quarterly Henrich R. Greve (INSEAD) and Professor Sheen S. Levine, Deputy Editor of MOR. The papers advocate presenting empirical data graphically to a greater degree than is currently the standard in management journals, as a way of highlighting their potential importance to connect the reader more effectively to evidence beyond the usual and customary statistical analyses. I thank Deputy Editor Professor Liisa Välikangas for commissioning these papers.

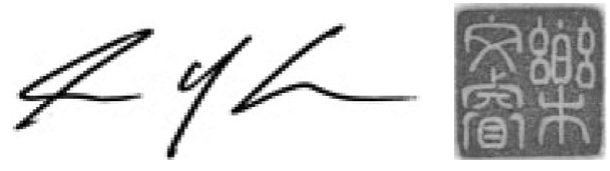

\section{REFERENGES}

De Massis, A., Majocchi, A., \& Piscitello, L. 2018. Family firms in the global economy: Toward a deeper understanding of internationalization determinants, processes, and outcomes. Global Strategy Journal. In press. Doi: 10.1002/gsj. 1199.

Florida, R. L., \& Kenney, M. 1988. Venture capital, high technology and regional development. Regional Studies, 22: 33-48.

Gomez-Mejia, L., Haynes, K. T., Núñez-Nickel, M., Jacobson, K. J. L., \& Moyano-Fuentes, J. 2007. Socioemotional wealth and business risks in family-controlled firms: Evidence from Spanish olive oil mills. Administrative Science Quarterly, 52(1): 106-137.

Lei, L. N. 2018. Mechanism study of strategic schemas on firm growth of Hidden Champions in Chinese manufacturing. PhD dissertation. Zhejiang University.

McKiernan, P., \& Purg, D. (Eds.) 2013. Hidden Champions in CEE and Turkey. Berlin: Springer-Verlag Berlin Heidelberg.

Miller, D., Le Breton-Miller, I., Lester, R., \& Canella, A. A. Jr. 2007. Are family firms really superior performers? Journal of Corporate Finance, 13(5): 829-858.

Simon, H. 1996. You don't have to be German to be a 'Hidden Champion'. Business Strategy Revieze, 7(20): 1-13.

Simon, H. 2009. Hidden Champions of the twenty-first century: Success strategies of unknown world market leaders. New York: Springer. 